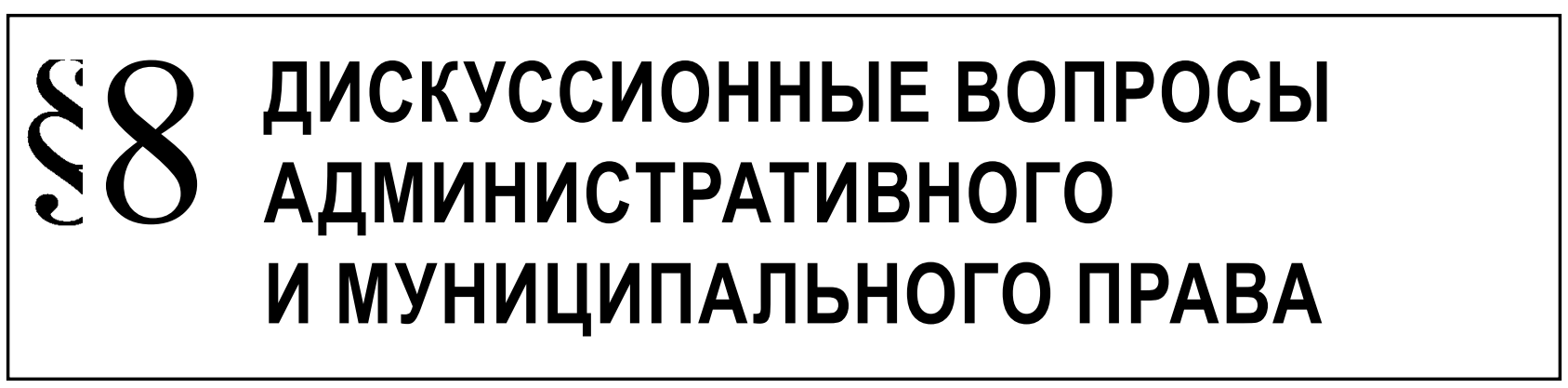

Винокуров А.Ю.

\title{
О НЕКОТОРЫХ ВОПРОСАХ ЗАКРЕПЛЕНИЯ В КОДИФИЦИРОВАННЫХ АКТАХ ГОСУДАРСТВ - УЧАСТНИКОВ СНГ ПОЛНОМОЧИЙ ПО ОСУЩЕСТВЛЕНИЮ АДМИНИСТРАТИВНОГО ПРЕСЛЕДОВАНИЯ
}

Аннотация. В статье проанализированы положения кодифицированных актов государств - участников Содружества Независимых Государств, регламентирующие полномочия прокуроров при осуществлении ими функции административного преследования. Автором подчеркнуты общие черты в развитии правового регулирования в указанных странах, а также имеющие место особенности, придающие уникальность правовому статусу прокуроров при применении ими норм законодательства об административных правонарушениях. Автор приходит к выводу об условном характере определения процессуального статуса прокуроров в разных странах как надзирающего должностного лица и участника производства по делу об административном правонарушении. В основе работы над статьей использован сравнительно-правовой метод изучения исходного материала - кодексов об административных правонарушениях девяти стран СНГ. Анализ доступной автору базы научных публикаций показал, что подобного рода работ, в которых комплексно исследовалась бы специфика правового регулирования деятельности органов прокуратуры сразу нескольких стран по осуществлению административного преследования, в настоящее время не имеется. Статья обладает научной новизной и является продолжением подготовленной ране автором статьи, посвященной анализу положений законов о прокуратуре стран СНГ.

Ключевые слова: административное правонарушение, административное прреследование, административное расследование, кодекс об административных, органы административной юрисдикции, органы прокуратуры, полномочия прокурора, постановление, участие в производстве, функция прокуратуры.

Review. The article analyzes the provisions of codified documents of the CIS member-states which regulate the functions of prosecutors in administrative prosecution. The author emphasizes the common traits of development of legal regulation in the mentioned countries, and the peculiarities of the legal status of prosecutors. The author comes to the conclusion about a relative character of definition of a procedural status of prosecutors as supervising officials and participants of administrative proceedings in different countries. The research is based on the comparative-legal method of study of the data - the codes of administrative offences of the nine CIS countries. The analysis of the available base of scientific publications demonstrates the lack of works studying the specificity of legal regulation of prosecutors' activities in several countries at once. Therefore, the present research is scientifically new; it continues the previous research of the author devoted to the analysis of the provisions of the laws on the prosecution in the CIS member-states.

Keywords: administrative offence, administrative prosecution, administrative investigation, Code of administrative offences, administrative jurisdiction bodies, public prosecutor's bodies, prosecutor's functions, decision, involvement in proceedings, public prosecutor's function.

$\mathrm{B}$ ранее изданной статье [1] нами были рассмотрены положения законодательных актов о прокуратуре государств, входящих либо входивших в содружество Независимых Государств, в которых получили закрепление полномочия прокуроров, связанные с реализацией функции административного преследование, а также впервые сформулировано авторское определение указанной деятельности. Насто- 
ящая статья является продолжением начатого нами сравнительно-правового исследования и в ее рамках полагаем необходимым рассмотреть специфику регулирования полномочий прокуроров при осуществлении административного преследования непосредственно кодифицированными актами государств постсоветского пространства. С учетом фактического отсутствия в доступной автору русскоязычной среде научных источников по рассматриваемому вопросу полагаем возможным ограничиться в качестве исходной базы текстами кодексов, регламентирующих вопросы реализации прокурорами полномочий, связанных с производством по делам об административных правонарушениях, которые мы относим к правовым инструментариям осуществления функции административного преследования. В качестве материала для сравнительно-правового исследования помимо Кодекса Российской Федерации об административных правонарушениях от 30.12.2001 № 195-ФЗ (далее - КоАП РФ) [2] использованы имеющиеся в русскоязычной версии кодифицированные акты девяти государств - Азербайджанской и Кыргызской республик, республик Беларусь, Казахстан, Молдовы, Таджикистан и Узбекистан, Туркменистана и Украины, что незначительно отличается от исследовательской базы, примененной в предыдущей статье (отсутствуют данные по Грузии и Республике Армения).

С учетом ограниченного объема статьи и в целях исключения неизбежных повторов полагаем возможным изложить основные выводы, к которым пришел автор в результате проведенного изучения соответствующих законодательных актов.

1. В большинстве государств имеет место кодификация в одном законодательном акте как непосредственно самих административных правонарушений, так и порядка производства по делам о них. Исключение составляет Процессуально-исполнительный кодекс Республики Беларусь об административных правонарушениях от 20.12.2006 № 194-3 (далее - ПИКоАП) [3], помимо которого имеется также Кодекс Республики Беларусь об административных правонарушениях от 21.04.2003 № 194-3 (далее - КоАП РБ) [4].

Наиболее распространение получило название «Кодекс об административных правонарушениях» (республики Казахстан [5] и Таджикистан [6], Туркменистан [7] и Украина [8]), которое имеет место и в Российской Федерации. В Кыргызской Республике [9] и Республике Узбекистан [10] культивируется понятие «Кодекс об административной ответственности». В Азербайджанской Республике [11] и Республике Молдова [12] наблюдается индивидуальный подход - соответственно «Кодекс об административных проступках» и «Кодекс о правонарушениях».

2. Сохраняя традиции советского периода в кодексах большинства государств (Азербайджанская Республика (ст. 368 КоАП АР), республики Беларусь (ст. 2.15 ПИКоАП) и Узбекистан (ст. 275 КоАО РУ), Туркменистан (ст. 436 КоАП Т) и Украина (ст. 250 КоАП У)) статус прокурора определен исключительно как надзорный. Вместе с тем среди «надзорных» полномочий можно вычленить и такие, которые с точки зрения высказанного нами в предыдущей статье подхода к характеристике полномочий являются административным преследованием и прежде всего речь идет о возбуждении прокурорами дел об административных правонарушениях.

3. В ряде государств (Кыргызская Республика (ст. 579 КоАО КР), республики Молдова (ст. 386 КоП М) и Таджикистан (ст. 780 КоАП РТ)) прокуроры называются исключительно в качестве участников производства по делам об административных правонарушениях. Однако, и здесь можно констатировать, что в части полномочий наблюдается присутствие наряду с ненадзорными сугубо надзорных, прежде всего связанных с проверкой законности в деятельности органов административной юрисдикции.

4. Двойным статусом, также как и в Российской Федерации (ст. ст. 24.6 и 25.11 КоАП РФ), наделены только прокуроры в Республике Казахстан (ст. ст. 759 и 760 КоАП РК), однако полноценное представление об этом несколько «смазывается» ввиду прямой отсылки ст. 759 Кодекса этой страны к ст. 760, раскрывающей надзорный статус прокурора. И здесь не вполне понятна логика законодателя, выраженная в словосочетании «в целях реализации своих полномочий, предусмотренных статьей 760 настоящего Кодекса, прокурор вправе», поскольку далее перечисляются соответствующие полномочия. То есть выходит, что прокурор применяет одни полномочия (как участник производства) в целях реализации других (надзорных).

В этой связи мы поддерживаем высказанную В.И. Ломакиным в диссертационном исследовании позицию о том, что «полномочия прокурора при участии в производстве по делу об административном правонарушении (имеется в виду - при рассмотрении дела судом) не равнозначны функциям надзора за соблюдением законов в этом производстве [13]. К сожалению, данный автор допускает свойственную и некоторым другим ошибку, говоря о надзорной функции во множественном числе. К тому же в ст. 24.6 КоАП РФ говорится о надзоре 
за исполнением, а не соблюдением законов. От себя добавим, что и при рассмотрении дела об административном правонарушении органом (должностным лицом органа) административной юрисдикции прокурор в качестве участника производства не может одновременно осуществлять надзор.

5. В большинстве приведенных кодифицированных актов, также как и в КоАП РФ, не конкретизируется, каким именно прокурором реализуются предусмотренные полномочия. Едва ли можно рассматривать в качестве конкретной формулировку «Генеральный прокурор Российской Федерации и назначаемые им прокуроры», приведенную в ст. 24.6 «Прокурорский надзор» КоАП РФ, где в принципе не называется ни одного полномочия [14].

Вместе с тем в Кодексе Украины прямо названы прокурор и заместитель прокурора (ст. 250). Кроме того, в этом же законодательном акте применяется словосочетание «прокурор или уполномоченное им лицо из числа работников прокуратуры» (п.п. 8 и 11 ст. 255).

В Кодексе Республики Казахстан говорится об осуществлении высшего надзора Генеральным Прокурором и подчиненными ему прокурорами (ст. 759). Такой же подход выдержан в ст. 745 Кодекса Республики Таджикистан.

Кодекс Кыргызской Республики оперирует понятием «уполномоченные на то должностные лица... органов прокуратуры» в контексте права составлять протоколы об административных правонарушениях (пп. 1 п. 1 ст. 556-1).

6. Во всех государствах прокуроры наделены правом инициирования производства по делу об административном правонарушении посредством вынесения постановления или составления протокола. При этом законы о прокуратуре Республики Молдова [15] и Украины [16], как отмечалось нами в указанной выше статье, такого полномочия прокурора прямо не называют, очевидно, в силу отсутствия закрепленной в них отрасли надзора за исполнением законов.

Среди перечисленных норм только в ПИКоАП право составления протокола об административных правонарушениях упоминается не среди прочих полномочий прокурора, а в ст. 3.30 , перечисляющей государственные органы, чьи должностные лица вправе принимать названные решения.

Вместе с тем, следует отметить, что в кодексах Кыргызской Республики и Украины имеет место рассогласование понятий, поскольку в названных в предыдущем пункте выводов соответственно статьях 556-1 и 255 говорится о «протоколах об административных правонарушениях», в то время как в статусных статьях применяется традиционное для прокуроров большинства стран «постановление». В своей статье А.О. Колотило отметил эту особенность, подчеркнув, что «российский прокурор не наделен правом составления протокола об административном правонарушении, тогда как согласно ст. 255 КУоАП в Украине такие полномочия у прокурора есть при выявлении коррупционных и некоторых иных административных правонарушений» [17], однако, полагаем, что читателю была бы интересна не констатация факта, а причина закрепления украинским законодателем сразу двух актов реагирования, с помощью которых прокурор вправе инициировать административное преследование;

7. В ряде государств, также как и в Российской Федерации, законодательно подчеркивается «исключительная компетенция» прокуроров в возбуждении дела об административном правонарушении. Названный термин получил определенное распространение в прокурорской науке [18] и означает прямое закрепление в законодательстве составов административных правонарушений, возбуждение дел о которых возложено непосредственно на прокурора. В административном праве для обозначения рассматриваемой ситуации применяется также понятие «исключительные полномочия» [19]. Правда, оговоримся, что на самом деле указание прокурора в контексте конкретного перечня статей того или иного кодекса отнюдь не означает «абсолютной исключительности», поскольку, во-первых, как и в Российской Федерации могут иметь место случаи наличия «дублеров» в лице должностных лиц органов административной юрисдикции, а, кроме того, также как и в России, законодатель в отдельных случаях закрепляет за прокурорами не только исключительное по отдельным составам правонарушений, но и абсолютное право фактически инициирования административного преследования по всем проступкам, выявленным в ходе осуществления надзорной деятельности.

Итак, в п. 7 ч. 2 ст. 3.30 ПИКоАП определено, что прокурор вправе составлять протоколы об административных правонарушениях, предусмотренных ст. ст. 9.6, 9.10, 9.13, 9.16, 9.19, 21.9, 21.10, 22.10, 23.16, $23.18,23.25$, ч. 2 ст. 23.26 , ст. ст. $23.37,23.38$, ч. 1 ст. 23.54, ч. 2 ст. 23.58 , ст. ст. $23.79-23.83,24.3$, ч. 3 ст 24.10 , ст. ст. $25.2-25.4$, ч. 2 ст. 25.8 КоАП РБ, а за иные административные правонарушения - при осуществлении надзорных функций. Отметим, как и выше применительно к диссертационной работе В.И. Ломакина, некоторую некорректность словосочетания «надзорные функции», поскольку речь идет все-таки об одной функции - прокурорском надзоре. 
Кроме того, наряду с должностными лицами других органов в силу п. 8 ч. 2 ст. 3.30 ПИКоАП прокуроры управомочены составлять протоколы по ст. ст. статьям 23.1-23.5, 24.4-24.6 КоАП РБ.

В части 1 ст. 805 Кодекса Республики Казахстан за прокурором закреплено право выносить постановление о возбуждении дел об административных правонарушениях, предусмотренных ст. ст. 74, $75,76,77,78,79,81,82,93,94,95,96,97,98,99,100$, $101,102,103,104,105,106,107,108,109,110,111$, $112,113,114,115,116,117,118,119,120,121,122$, $123,124,125,126,129,130,173,189,214,361,362$, $363,439,451,452,453,455,456,457,465,490,498$, 507, 508, 653, 660, 666, 675, 680 КоАП РК. Вместе с тем согласно ч. 2 указанной статьи прокурор вправе вынести постановление о возбуждении дела и об ином административном правонарушении.

Пунктом 1 ч. 1 ст. 556-1 Кодекса Кыргызской Республики уполномоченные на то должностные лица органов прокуратуры уполномочены инициировать административное преследование по ст. ст. 49, 50, 51, $52,53,54,55,56,57,58,59,61,61-1,62,63,64,66-2,66$ 7, 67, 82-1, 400, 400-3, 404, 406, 409-1 КоАО КР.

Наконец, по Кодексу Украины прокуроры или уполномоченные ими лица из числа работников прокуратуры возбуждают дела об административных правонарушениях, ответственность за совершение которых предусмотрена:

- частью четвертой ст. 184, ст. 185-4, частью второй ст. 185-6, ст. ст. 185-8, 185-11 (п. 8 ст. 255 КоАП У);

- частью третьей ст. 127-1, ст. ст. 172-2 - 172-9, 188-32, 188-35, 212-3 (п. 11 ст. 255 КоАП У).

8. В отличие от норм законов о прокуратуре, включая Федеральный закон от 17.01.1992 № 2202-1 «0 прокуратуре Российской Федерации» [20], где в качестве субъектов, преследуемых прокурором в административном порядке, выступают должностные лица, реже граждане, кодифицированные акты не ограничивают прокурора, и в случае если субъектом административного правонарушения выступает юридическое лицо, прокурор вправе возбуждать дело и в отношении него.

9. Уникальное полномочие закреплено в ст. 9.4 «Административный процесс по требованию» ПИКоАП, согласно которой в случае совершения деяний, предусмотренных ст. 9.1 КоАП РБ, административный процесс может быть начат прокурором при отсутствии требования (речь идет о требовании потерпевшего либо законного представителя привлечь лицо, совершившее административное правонарушение, к административной ответственности, выраженном в форме заявления) и не подлежит пре- кращению в случае примирения потерпевшего либо законного представителя с лицом, в отношении которого ведется административный процесс.

10. Помимо Российской Федерации, прокуроры еще в трех странах (Азербайджанской Республике, Республике Таджикистан и Туркменистане наделены правом инициировать проведение административного расследования.

Согласно ч. 2 ст. 413 КоАП АР прокурором выносится постановление о возбуждении производства по делу об административном проступке и о проведении административного расследования. Частью 2 ст. 747 КоАП РТ определено, что решение о возбуждении дела об административном правонарущении и проведении административного расследования принимается прокурором в виде постановления. В свою очередь, в соответствии с ч. 2 ст. 535 КоАП Т прокурор имеет право выносить постановление о возбуждении административного производства и проведении административного расследования.

К сожалению, как и в случае со ст. 28.7 КоАП РФ законодательно не отражено, какие дальнейшие действия после вынесения указанного постановления должен предпринять прокурор [21].

11. Только в Республике Узбекистан некоторые прокуроры (должностные лица Департамента по борьбе с налоговыми, валютными преступлениями и легализацией преступных доходов при Генеральной прокуратуре Республики Узбекистан и его подразделений на местах) уполномочены применять ряд мер обеспечения производства по делу об административном правонарушении, а именно:

- административное задержание при совершении перечисленных выше правонарушений (п. 8 ст. 287 КоАО РУ);

- досмотр вещей (ст. 289 КоАО РУ);

- изъятие вещей и документов (ст. 290 КоАО РУ).

- задержание и досмотр транспортных средств при совершении административных правонарушений, предусмотренных ст. ст. 164, $166,167,168,172,173,176,176-3,186-1$ Кодекса (п. «Д» ст. 291 КоАО РУ).

12. Также к числу уникальных следует отнести наличие в Кодексе Казахстана главы 49 «Особенности производства по делам лиц, обладающих привилегиями и иммунитетом от административной ответственности», закрепляющей определенные полномочия прокурора, связанные с административным преследованием соответствующих субъектов.

Так, частью 2 ст. 870 КоАП РК определено, что для получения согласия на привлечение деnymama 
Парламента Республики Казахстан к административной ответственности, влекущей наложение административного взыскания в судебном порядке, привод Генеральный Прокурор Республики Казахстан вносит представление в соответствующую Палату Парламента Республики Казахстан, депутатом которой является лицо, совершившее административное правонарушение.

В свою очередь в силу ч. 2 ст. 871 КоАП РК представление о привлечении кандидата в Президенты Республики Казахстан, в депутаты Парламента Республики Казахстан к административной ответственности вносится в Центральную избирательную комиссию Республики Казахстан Генеральным Прокурором Республики Казахстан перед направлением дела об административном правонарушении в суд.

В соответствии с ч. 2 ст. 872 КоАП РК для получения согласия на привлечение Председателя или членов Конституционного Совета Республики Казахстан к административной ответственности, влекущей наложение административного взыскания в судебном порядке, привод Генеральный Прокурор Республики Казахстан вносит представление в Парламент Республики Казахстан.

Частью 2 ст. 873 КоАП РК установлено, что для получения согласия на привлечение судьи к административной ответственности, влекущей наложение административного взыскания в судебном порядке, привод Генеральный Прокурор Республики Казахстан вносит представление Президенту Республики Казахстан, а в случае, предусмотренном пп. 3 ст. 55 Конституции, - в Сенат Парламента Республики Казахстан. Представление вносится перед направлением дела об административном правонарушении в суд, решением вопроса о необходимости принудительного доставления судьи в суд, орган (к должностному лицу), уполномоченные рассматривать дела об административных правонарушениях.

Наконец, особое место занимает процедура привлечения к административной ответственности самого Генерального Прокурора Республики Казахстан, который согласно ч. 1 ст. 874 КоАП РК в течение срока своих полномочий не может быть подвергнут приводу, мерам административного взыскания, налагаемым в судебном порядке, без согласия Сената Парламента Республики Казахстан. А для получения согласия на привлечение его к административной ответственности, влекущей наложение административного взыскания в судебном порядке, привод первый заместитель Генерального Прокурора вносит представление в Сенат Парламента Республики Казахстан.
13. Исключительно в Республике Молдова прокурор вправе рассматривать дела о правонарушениях, предусмотренных ст. ст. 54-1, 63-68, 88, 312, $313,313-3,316,317,320,323,324,335-337,351-353$ КоП М, и правонарушениях, выявленных им при исполнении обязанностей (ст. 396 Кодекса Республики Молдовы), и назначать наказания, кроме относящихся к исключительной компетенции суда.

14. В республиках Беларусь и Казахстан, как отмечалось при характеристике соответствующих законов о прокуратуре в указанной выше статье, у прокуроров имеются полномочия, которые можно рассматривать в контексте процессуального руководства органами административной юрисдикции.

Так, согласно п. 8 ч. 2 ст. 2.15 ПИКоАП прокурор вправе поручать органу, ведущему административный процесс, подготовку дела об административном правонарушении для рассмотрения (по административным правонарушениям, протоколы по которым не составляются прокурором). В свою очередь в силу п. 2 ч. 1 ст. 760 КоАП РК прокурор может давать письменные указания уполномоченным долэностным лицам и органам (кроме суда) о производстве дополнительной проверки. К слову, В.И. Ломакин в пункте 3 положений, выносимых на защиту, своего диссертационного исследования [13] предлагает дополнить ст. 25.11 КоАП РФ в том числе и правом прокурора давать письменные указания уполномоченным должностным лицам и органам (кроме суда) о проведении дополнительных проверок и приобщении дополнительных документов и материалов по делам об административных правонарушениях, находящимся в их производстве.

15. Стандартным набором полномочий по участию в рассмотрении дел об административных правонарушениях, заявлению ходатайств и даче заключений по вопросам, возникающим во время рассмотрения дела, наделены прокуроры практически во всех названных выше кодифицированных актах. При этом следует отметить, что далеко не везде закреплены нормы, предписывающие уведомлять прокурора о месте и времени рассмотрения дела об административном правонарушении. Кроме того, имеет место различия в подходах к основаниям для соответствующего уведомления прокурора.

Так, согласно ч. 4 ст. 368 Кодекса Азербайджанской Республики прокурор уведомляется о месте и времени рассмотрения дел об административных проступках в отношении несовершеннолетних, а также дел, возбужденных по его инициативе. Это фактически дословно совпадает с ч. 2 ст. 25.11 
КоАП РФ. Аналогичное требование содержится в ч. 2 ст. 780 Кодекса Республики Таджикистан.

В соответствии с ч. 3 ст. 759 Кодекса Республики Казахстан прокурор в обязательном порядке извещается о месте и времени рассмотрения дела об административном правонарушении, совершенном несовершеннолетним лицом, а также правонарушении, влекущем административный арест. При этом в его отсутствие такое дело может быть рассмотрено лишь в случае, когда имеются данные о своевременном извещении прокурора о месте и времени рассмотрения дела и если от него не поступило ходатайство об отложении рассмотрения дела.

Наконец, в силу ч. 4 ст. 436 Кодекса Туркменистана прокурор должен уведомляться о времени и месте рассмотрения дела об административном правонарушении в отношении несовершеннолетних, беременных женщин, женщин, имеющих детей в возрасте до восьми лет, лии, имеющих право на пенсию по возрасту или на государственное социальное пособие, лиц с инвалидностью I и ІІ группы, а также дела об административном правонарушении, возбуждённого по инициативе прокурора.

Кроме того, особо подчеркнем, что согласно части второй ст. 250 Кодекса Украины при произ- водстве по делам об административных правонарушениях, предусмотренных статьями $172^{2}-172^{9}$ Кодекса, участие прокурора в рассмотрении дела судом является обязательным.

16. Пожалуй, в качестве самой специфической индивидуальности следует выделить наличие только в КоАП РФ главы 29.1 «Правовая помощь по делам об административных правонарушениях», в которой значительное место отводится органам прокуратуры.

Таким образом, подводя итог проведенному сравнительно-правовому исследованию, отметим, что, в проанализированных кодифицированных актах государств постсоветского пространства просматриваются как общие, так и специфические черты, отражающие статус прокурора при реализации им полномочий. При этом независимо от того, является ли этот статус сугубо надзорным, закреплена ли роль прокурора исключительно как участника производства по делам об административных правонарушениях либо он позиционируется и в том и в другом качестве, всегда можно отделить надзорные полномочия от ненадзорных, часть которых мы относим к реализуемым в рамках функции административного преследования.

\section{Библиография:}

1. Винокуров А.Ю. О некоторых вопросах правового регулирования деятельности ор-ганов прокуратуры государств - участников СНГ по осуществлению административного преследования // Административное и муниципальное право. - 2015. - № . - С. 2.

2. СЗ РФ. - 2002. - № 1 (ч. 1). - Ст. 1 (с послед. изменениями).

3. http://www.pravo.by. Национальный правовой Интернет-портал Республики Бела-русь. Дата обращения - 28.04.2015.

4. http://www.pravo.by. Национальный правовой Интернет-портал Республики Бела-русь. Дата обращения - 28.04.2015.

5. Кодекс Республики Казахстан об административных правонарушениях от 05.07.2014 № 235-V 3РК (далее КоАП РК или Кодекс Республики Казахстан) // Ведомо-сти Парламента Республики Казахстан. - 2014. - № 18-II (2667-II). - Ст. 92 (с послед. из-менениями).

6. Кодекс Республики Таджикистан об административных правонарушениях: при-нят и введен в действие Законом Республики Таджикистан от 31.12.2008 № 455 (далее - КоАП РТ или Кодекс Республики Таджикистан) // Ахбори Маджлиси Оли Республики Таджикистан. - 2008. - № 12 (ч. 1). - Ст. 989 (с послед. изменениями).

7. Кодекс Туркменистана об административных правонарушениях: утвержден и вве-ден в действие Законом Туркменистана от 29.08.2013 (далее - КоАП Т или Кодекс Турк-менистана) // Электронная газета «Туркменистан: золотой век».

8. Кодекс Украины об административных правонарушениях от 07.12.1984 № 8073-Х (далее - КоАП У или Кодекс Украины) // Ведомости Верховной Рады Украинской ССР. - 1984. - № 51 (с послед. изменениями).

9. Кодекс Кыргызской Республики об административной ответственности от 04.08.1998 № 114 (далее - КоАО КР или Кодекс Кыргызской Республики) // Ведомости Жогорку Кенеша Кыргызской Республики. - 1999. - № 2. - Ст. 77 (с послед. изменения-ми).

10. Кодекс Республики Узбекистан об административной ответственности: утвер-жден Законом Республики Узбекистан от 22.09.1994 № 2015-XII (далее - КоАО РУ или Кодекс Республики Узбекистан) // Ведомости Верховного Совета Республики Узбекистан. - 1995. - № 3.

11. Кодекс Азербайджанской Республики об административных проступках: утвер-жден Законом Азербайджанской Республики от 11.07.2000 № 906-IQ (далее - КоАП АР или Кодекс Азербайджанской Республики) // Собрание законодательства Азербайджан-ской Республики. - 2000. - № 8 (кн. 1). - Ст. 584 (с послед. изменениями).

12. Кодекс Республики Молдова от 24.10.2008 № 218-XVI «О правонарушениях» (далее - КоП М или Кодекс Республики Молдова) // Официальный монитор Республики Молдова от 16.01.2009 № 3-6/15 (с послед. изменениями).

13. Ломакин В.И. Прокурор в производстве по делам об административных правона-рушениях: дисс. на соиск. учен. степ. канд. юрид. наук (12.00.14). - Челябинск, 2006. - С. 107. 
14. Винокуров А.Ю. К вопросу об идентификации понятия «прокурор» при примене-нии Кодекса Российской Федерации об административных правонарушениях // Админи-стративное и муниципальное право. - 2014. № 7. - С. 665-672.

15. Закон Республики Молдова от 25.12.2008 № 294 «О прокуратуре» // Base.spinform.ru. Законодательство стран СНГ. Дата обращения - 28.04.2015.

16. Закон Украины от 14.10.2014 № 1697-VII «О прокуратуре» // Голос Украины от 25.10.2014 № 206.

17. Колотило А.О. Статус прокурора в производстве по делам об административных правонарушениях в России и Украине // Законность. - 2013. - № 2.

18. Ергашев E.P. О проблемах нормативного регулирования применения постанов-ления о возбуждении административного производства как акта прокурорского реагиро-вания // Бизнес, Менеджмент и Право. - 2012. - № 2; Ломакин В.И. Указ. соч. - С. 58 и др.

19. Салищева Н.Г. В кн.: Комментарий к Кодексу Российской Федерации об админи-стративных правонарушениях (постатейный) / под общ. ред. Н.Г. Салищевой. - 7-е изда-ние. - М.: Проспект, 2011 // СПС «КонсультантПлюс.

20. СЗ РФ. - 1995. - № 47. - Ст. 4472 (с послед. изменениями).

21. Винокуров А.Ю., Винокуров Ю.Е. О новом взгляде на полномочия прокурора, свя-занные с применением Кодекса Российской Федерации об административных правонару-шениях // Административное и муниципальное права. - 2012. - № 5. - С. 34-38.

\section{References (transliterated):}

1. Vinokurov A.Yu. O nekotorykh voprosakh pravovogo regulirovaniya deyatel'nosti or-ganov prokuratury gosudarstv - uchastnikov SNG po osushchestvleniyu administrativnogo presledovaniya // Administrativnoe i munitsipal'noe pravo. - 2015. - № . - S. 2.

2. SZ RF. - 2002. - № 1 (ch. 1). - St. 1 (s posled. izmeneniyami).

3. http://www.pravo.by. Natsional'nyi pravovoi Internet-portal Respubliki Bela-rus'. Data obrashcheniya - 28.04.2015.

4. http://www.pravo.by. Natsional'nyi pravovoi Internet-portal Respubliki Bela-rus'. Data obrashcheniya - 28.04.2015.

5. Kodeks Respubliki Kazakhstan ob administrativnykh pravonarusheniyakh ot 05.07.2014 № 235-V ZRK (dalee - KoAP RK ili Kodeks Respubliki Kazakhstan) // Vedomo-sti Parlamenta Respubliki Kazakhstan. - 2014. - № 18-II (2667-II). - St. 92 (s posled. iz-meneniyami).

6. Kodeks Respubliki Tadzhikistan ob administrativnykh pravonarusheniyakh: pri-nyat i vveden v deistvie Zakonom Respubliki Tadzhikistan ot 31.12.2008 № 455 (dalee - KoAP RT ili Kodeks Respubliki Tadzhikistan) // Akhbori Madzhlisi Oli Respubliki Tadzhikistan. - 2008. - № 12 (ch. 1). - St. 989 (s posled. izmeneniyami).

7. Kodeks Turkmenistana ob administrativnykh pravonarusheniyakh: utverzhden i vve-den v deistvie Zakonom Turkmenistana ot 29.08.2013 (dalee - KoAP T ili Kodeks Turk-menistana) // Elektronnaya gazeta «Turkmenistan: zolotoi vek».

8. Kodeks Ukrainy ob administrativnykh pravonarusheniyakh ot 07.12.1984 № 8073-X (dalee - KoAP U ili Kodeks Ukrainy) // Vedomosti Verkhovnoi Rady Ukrainskoi SSR. - 1984. - № 51 (s posled. izmeneniyami).

9. Kodeks Kyrgyzskoi Respubliki ob administrativnoi otvetstvennosti ot 04.08.1998 № 114 (dalee - KoAO KR ili Kodeks Kyrgyzskoi Respubliki) // Vedomosti Zhogorku Kenesha Kyrgyzskoi Respubliki. - 1999. - № 2. - St. 77 (s posled. izmeneniya-mi).

10. Kodeks Respubliki Uzbekistan ob administrativnoi otvetstvennosti: utver-zhden Zakonom Respubliki Uzbekistan ot 22.09.1994 № 2015-XII (dalee - KoAO RU ili Kodeks Respubliki Uzbekistan) // Vedomosti Verkhovnogo Soveta Respubliki Uzbekistan. - 1995. - № 3.

11. Kodeks Azerbaidzhanskoi Respubliki ob administrativnykh prostupkakh: utver-zhden Zakonom Azerbaidzhanskoi Respubliki ot 11.07.2000 № 906-IQ (dalee- KoAP AR ili Kodeks Azerbaidzhanskoi Respubliki) // Sobranie zakonodatel'stva Azerbaidzhan-skoi Respubliki. - 2000. - № 8 (kn. 1). - St. 584 (s posled. izmeneniyami).

12. Kodeks Respubliki Moldova ot 24.10.2008 № 218-XVI «O pravonarusheniyakh» (dalee - KoP M ili Kodeks Respubliki Moldova) // Ofitsial'nyi monitor Respubliki Moldova ot 16.01.2009 № 3-6/15 (s posled. izmeneniyami).

13. Lomakin V.I. Prokuror v proizvodstve po delam ob administrativnykh pravona-rusheniyakh: diss. na soisk. uchen. step. kand. yurid. nauk (12.00.14). - Chelyabinsk, 2006. - S. 107.

14. Vinokurov A.Yu. K voprosu ob identifikatsii ponyatiya «prokuror» pri primene-nii Kodeksa Rossiiskoi Federatsii ob administrativnykh pravonarusheniyakh // Admini-strativnoe i munitsipal'noe pravo. - 2014. - № 7. - S. 665-672.

15. Zakon Respubliki Moldova ot 25.12.2008 № 294 «O prokurature» // Base.spinform.ru. Zakonodatel'stvo stran SNG. Data obrashcheniya - 28.04.2015.

16. Zakon Ukrainy ot 14.10.2014 № 1697-VII «O prokurature» // Golos Ukrainy ot 25.10.2014 № 206.

17. Kolotilo A.O. Status prokurora v proizvodstve po delam ob administrativnykh pravonarusheniyakh v Rossii i Ukraine // Zakonnost'. - 2013. - № 2.

18. Ergashev E.R. O problemakh normativnogo regulirovaniya primeneniya postanov-leniya o vozbuzhdenii administrativnogo proizvodstva kak akta prokurorskogo reagiro-vaniya // Biznes, Menedzhment i Pravo. - 2012. - № 2; Lomakin V.I. Ukaz. soch. - S. 58 i dr.

19. Salishcheva N.G. V kn.: Kommentarii k Kodeksu Rossiiskoi Federatsii ob admini-strativnykh pravonarusheniyakh (postateinyi) / pod obshch. red. N.G. Salishchevoi. - 7-e izda-nie. - M.: Prospekt, 2011 // SPS «Konsul'tantPlyus.

20. SZ RF. - 1995. - № 47. - St. 4472 (s posled. izmeneniyami).

21. Vinokurov A.Yu., Vinokurov Yu.E. O novom vzglyade na polnomochiya prokurora, svya-zannye s primeneniem Kodeksa Rossiiskoi Federatsii ob administrativnykh pravonaru-sheniyakh // Administrativnoe i munitsipal'noe prava. - 2012. № 5. - S. 34-38. 